\title{
THE PAYMENT OF TRUST-ACCOUNT INTEREST: THE ETHICAL DUTIES OF ATTORNEYS TOWARDS THEIR CLIENTS, AND THE IMPLICATIONS OF THE NEW LEGAL PRACTICE BILL
}

Introduction

It has been a long-standing practice in South Africa that interest earned on certain moneys deposited into attorneys' trust accounts is paid over to the Attorneys Fidelity Fund (hereinafter "AFF"). In fact, it is a legal requirement in terms of the Attorneys Act 53 of 1979 ("the Attorneys' Act"), and the current version of the Legal Practice Bill. (Law Society of South Africa (LSSA) http://www.Issa.org.za/upload/Legal\%20Practice\%20Bill\%20Decem ber\%202010.pdf accessed 2011-03-01). The December 2010 version of the Legal Practice Bill is the latest version of the Bill but not the final version, which is still awaited.

This practice has both ethical and legal implications that have to be considered.

This note will begin by looking at both the background and purpose of trust moneys received by attorneys. Then, using the KwaZulu-Natal Law Society Rules and schedules as a reference point (the KwaZulu-Natal Rules are generally representative, and in conformity with most of the rules of all the constituent law societies of the LSSA), the issue of whether the current practice of diverting the interest on trust moneys to the AFF is legally and ethically justifiable, particularly the duty to disclose information in respect of interest accruing on trust moneys, will be discussed. This will include a consideration of the proposed amendments in the new draft Legal Practice Bill. (The latest version of the draft Legal Practice Bill was released in December 2010. In 2002, there were two draft versions of the Legal Practice Bill, one drafted by the Law Society of South Africa and one drafted by the Advocates' Profession. After protracted negotiations and deliberations, these two drafts culminated in the first working draft of the Legal Practice Bill, released in 2009. Law Society of South Africa Website, http://www.Issa. org.za/upload/Legal_Practiuce_Bill_draft_1.pdf accessed 2012-03-27.)

\section{2} The purpose and statutory background of trust
moneys deposited with attorneys

An attorney's trust account is a separate banking account that the attorney is obliged to open in terms of section 78(1) of the Attorneys' Act when holding a client's money for litigation or other legal purposes. The reason for keeping a separate trust-banking account is to segregate the client's money from the attorney's personal business accounts, and in so doing to protect and safeguard the client's money (Law Society, Transvaal v Matthews 19892 ALL SA 1995 (T)). 
Up until March 1990, the Attorneys' Act allowed the attorney to open an additional trust account at his own discretion (s 78(2)(a)). This account was to be a separate trust-savings or other interest-bearing account in which any money that had been deposited in the current trust-banking account (whether for litigation or other legal purposes, such as conveyancing fees and payments - the Attorneys' Act does not distinguish between moneys invested for different purposes) that is not immediately required, may be deposited. Any interest earned on these two accounts was to be paid over to the AFF (s 78(3)).

After 1 March 1990, a further sub-section to $S 78$ was inserted into the Act (s 78(2A) by the Attorneys' Amendment Act 87 of 1989). Section 78(2A) now allows practitioners to open a third separate trust-savings or other interestbearing account, for the purpose of investing any money deposited in their trust-banking accounts. This account, however, will only be opened on the instructions of the client (in practice, of course, should this provision be brought to the attention of the client, it is highly unlikely that the client would choose to forego interest on the trust money; and the question as to whether the attorney has a duty to bring this provision to the attention of the client is one of the issues dealt with in this article), and, unlike the position with section 78(2)(a), interest earned on a section 78(2A) trust account accrues to the client. (Ref. S. 1429/95 - S 2.1 of the Guideline on s 78(2A), issued by the LSSA, on behalf of the attorneys' profession, and the Institute of Chartered Accountants to assist practitioners to apply $s 78(2 \mathrm{~A})$ in their practice.)

The current position of attorneys' trust accounts, as summarized on the AFF website (http://www.fidfund.co.za/category/banking-options accessed 2012-02-23):

"Trust investments are made for the benefit of the Fund in terms of section

78 (2)(a) of the Act, or for the benefit of clients in terms of section 78(2A)."

It appears that section 78(2A) which has been used as a "back door" (s $78(2 \mathrm{~A})$ of the Attorneys' Act does not explicitly provide that interest earned on this account must be paid to the client; this is, however, the effect of this provision when read with the Guideline on s 78(2A) [Ref. S. 1429/95], and s 78(3), which expressly provides that interest earned on $s$ 78(2)(a) and (2)(b) accounts be paid to the Fidelity Fund; and as $s 78(3)$ is silent on trust-fund interest earned in terms of $s 78(2 A)$, this permitted the payment of this interest to the client rather than the Fidelity Fund) amendment in order to enable practitioners to pay interest earned in terms of trust deposits made in terms of sub-section (2A) to the client, and not to the AFF. However, the current version of the Legal Practice Bill purports to change the status quo in this regard.

\section{$3 \quad$ Trust-fund interest provisions in the Legal Practice Bill, 2010 (approved by the Cabinet on 8 December 2010)}

The second draft of the Legal Practice Bill (published in April 2010) contained provisions relating to interest earned on attorneys' trust accounts 
that were essentially the same as in the current Attorneys' Act (53 of 1979), except that sub-section (2A) was incorporated in section 101 of this Bill (s 101 of the Legal Practice Bill (second draft, April 2010) - Attorneys Obliged to Hold Fidelity Fund Certificates Must Open Trust Accounts). This April 2010 version was revised and the current version of the Bill was released in December 2010.

As with the Attorneys' Act (53 of 1979) and the April 2010 Legal Practice Bill, this version obliges practitioners to open a separate current trustbanking account and to deposit therein any money received by them on accounts of any persons (s 88(2) (s 88 - Attorneys Obliged to Open Trust Accounts). It also allows practitioners to invest in a separate trust-savings account or other interest-bearing account any money which is not immediately required for any particular purpose (s 88(3)(a)), and to open a separate trust-savings account or other interest-bearing account for the purpose of investing therein any money deposited in the trust account of that practice on the instructions of any person (s 88(4)(a)).

However, section 88(5) of the current Bill differs from the April 2010 version and the Attorneys' Act, in that it provides that any interest accrued on money deposited in any of the three accounts must be paid over to the Fund.

In terms of this Bill then, the client is not entitled to any interest accruing on his money deposited in a legal practitioner's trust account. This Bill does not provide a "back-door"-interest clause similar to section $78(2 \mathrm{~A})$ of the Attorneys' Act. This omission has recently attracted much comment and attention, in particular in representations by the Law Society of South Africa (LSSA) on the Legal Practice Bill in May 2011.

\section{Representations by the LSSA on the Legal Practice Bill (December 2010)}

In response to the removal of the option to pay trust-account interest to the client (instead of the AFF), representations were made to the Department of Justice and Constitutional Development as a matter of urgency by the Law Society of South Africa (LSSA) on 26 May 2011. The LSSA motivated to amend section 88(5) of the December 2010 draft version of the Legal Practice Bill to revert to the position set out in the April 2010 version of the Legal Practice Bill, which essentially replicated the position in the Attorneys' Act, 1979.

The LSSA proposed, therefore, that where no specific client request was received, interest accruing on moneys paid into an attorney's current trust account, or moneys not immediately needed that are paid into an interestbearing account, must be paid over to the AFF. In contrast, interest accruing on moneys paid into an interest-bearing account, opened at the request of the client, be paid over to the client. (Confirming the position set out in S 2.1 of the Guideline on Section 78(2A) of the Attorneys' Act; and also see Ref. S. $1429 / 95-S 2.1$ of the Guideline on S 78(2A), issued by the LSSA, on behalf of the attorneys' profession, and the Institute of Chartered Accountants to assist practitioners to apply s $78(2 \mathrm{~A})$ in their practice.) 
The LSSA motivated their submission by saying that section $88(5)$ would have serious and far-reaching implications for the clients of attorneys, particularly in relation to conveyancing transactions. In conveyancing transactions, large amounts of money are frequently deposited in respect of costs and transfer duties to be held in trust pending finalization of the transaction. They submitted that denying a client the right to earn interest on his money in these transactions, which often take some time to finalize, would be financially highly prejudicial to the client, and "materially disrupt a convention relating to the transfer of immovable property which had existed for decades" (see, eg, the letter by John Gilchrist July 2011 De Rebus 4).

The LSSA motivated further that denying attorneys' clients the right to any interest at all on their money would discourage the clients from leaving any of their money in the attorneys' trust accounts, whether for conveyancing or otherwise. They would rather leave their money in the bank and issue a bank guarantee for the necessary amount. The LSSA concluded that, "The effect of this would be that the Fund would be deprived of the 'general' interest on the amount paid to the attorneys' trust accounts for the purpose of investment - it may only be for one day, but cumulatively it would amount to a huge loss."

Against this background, the ethical duties of attorneys to their clients with regard to the payment of trust moneys, and, in particular, the right to receive interest on trust moneys, will be considered.

\section{$5 \quad$ Current ethical duties of attorneys to their clients in respect of interest accruing on trust moneys}

The general ethical duties of legal practitioners are set out in the KwaZuluNatal Law Society Rules and schedules to the rules, and the KwaZulu-Natal Law Society Rulings, which are a gloss upon, and must be read in conjunction with the Rules. In addition, the International Bar Association (IBA) General Principles for the Legal Profession (2006) are incorporated in the $14^{\text {th }}$ schedule of the KwaZulu-Natal Law Society Rules (the $14^{\text {th }}$ Schedule was inserted by GG 3287222 January 2010).

The introduction to the IBA General Principles states that, "Lawyers throughout the world are specialised professionals who place the interests of their clients above their own, and strive to obtain respect for the Rule of Law." The 5th principle goes on to state that, "A lawyer shall treat the interests of his or her clients as paramount, subject always to his or her duties to the Court and the interests of justice, to observe the law and to maintain ethical standards".

The introduction to the KwaZulu-Natal Rulings states that:

"The attorney and client relationship is characterised by the trust which the client places in his attorney. Lacking the technical skills, knowledge and objectivity necessary to form his own judgment, the client places himself in the hands of his attorney in the knowledge that his secrets will remain confidential, his property will be secure and the advice which he receives will be informed and directed towards his best interests." 
The Rulings, in explaining the essence of the professional conduct of an attorney, quote Sir Thomas Lund CBE when he said: "You may well ask for a short summary of a solicitor's duties. I suppose really
it is the old principle of "do unto others as you would they should do unto you'.
If I had to advise briefly the young solicitor on the guiding principles of conduct
when he comes into the profession, I think I should say to him that it is clear
that only the very highest conduct is consistent with membership of this
profession of ours. Your client's interests are paramount - that seems to be
clear ..."

The key question is to what extent the "interests" of the client include the client's financial interests, and, in particular, the legal and ethical duty of the attorney to inform the client about all aspects of the client's right to interest on the moneys held in trust for him.

The KwaZulu-Natal Law Society Rules deal with misconduct in the legal profession in section 14, which stipulates that unprofessional, dishonourable or unworthy conduct on the part of a member shall include a breach of faith or trust in relation to his client. The term "breach of faith or trust" is clarified in the Rulings as being improper for a member to take advantage of the inexperience, youth, want of education, ill-health, lack of knowledge or unbusinesslike habits of a client. (S 14(b)(ii). The following is also considered misconduct in terms of s 14 of the Rules: s 14(b)(xvii)-failing to comply with any Rule of the International Code of Ethics of the International Bar Association; s 14(b)(xxv)-failing to comply with any Rule of the Code of Ethics for Legal Practitioners; and s 14(b)(xxvii)-failing to disclose to the person on whose behalf a s $78(2 \mathrm{~A})$ investment is made, the reasonable fee charged for the administering of such investment.) In addition, the rulings state: that in pecuniary matters, a member must be punctual and diligent. $\mathrm{He}$ should not retain money which he has received for his client without good reason.

From the above it is clear that the "pecuniary" interests of the client fall within the overall "interests" of the client that the attorney must safeguard. As the loss the client may suffer as a result of not receiving interest on trust moneys that he may have been entitled to clearly forms part of the client's "pecuniary interests", it follows that this is also an interest that the attorney is ethically obliged to observe.

Section 78(2A) of the Attorneys' Act, strictly interpreted, only obliges the attorney to invest moneys not immediately required, in a separate interestbearing trust account, which interest will accrue to the client, if the client requests that this be done. Therefore, it appears that there is no legal obligation on the attorney to inform the client of this provision if the request is not forthcoming. As a matter of ethics, however, the attorney has a duty to take into account the client's lack of experience and business acumen, which would, in our view, impose an ethical obligation on the attorney to inform the client of his section 78(2A) option to receive interest, even in circumstances where no such request has been made. (KwaZulu-Natal Law Society Rulings on s 14 of the KwaZulu-Natal Law Society Rules. As the client would not have knowledge of his right to obtain interest in terms of $\mathrm{s}$ $78(2 \mathrm{~A})$, the attorney has an ethical duty to inform him of this right in order to remedy this lack of knowledge. It is certainly also not good business practice 
- therefore an "unbusinesslike habit" - to forego interest voluntarily which you could choose to receive. This is analogous to the legal duty contained in s 35(1) of the Constitution, not only entrenching an arrested person's right to silence, but the duty to inform him of this right to silence to make the right effective. In any event, it is highly unlikely that this option would not be disclosed voluntarily by the attorney to a client about to deposit a very large sum into the attorney's trust account.)

\section{Conclusion}

In principle, therefore, following from the above, it is submitted that the attorney has an ethical duty to inform the client of all options available to him in law regarding the allocation of interest on trust moneys paid to the attorney by the client, to enable the client to make an informed decision. Unlikely as it may appear, the client may actually choose to forego his potential trust-account interest - but this must be the informed choice of the client, and not due to the withholding of information by the attorney. (A client may consider it his duty to contribute to the Attorneys' Fidelity Fund for the general public benefit.)

Conversely, an argument may be made that the attorney also has a duty not to undermine the AFF as this fund is ultimately applied for the benefit of the public as a whole (whilst the Fidelity Fund is essentially applied for professional indemnity insurance in terms of $s 45(1)(h)$, the contents of this fund are also used for administrative expenses, bursaries for law students, grants to universities and law clinics, and travelling expenses: see Attorneys Fidelity Fund Annual Report 2011). Even working from the premise that these funds must be construed as being applied for the public benefit (a counter-argument may be made that there is no moral basis to expect the general public to fund the public indemnity insurance premiums of attorneys effectively), any duty an attorney may have towards the AFF is outweighed by the duty to act in the best interests of the client, as the latter duty is paramount.

Finally, it was noted above that the latest proposed version of the Legal Practice Bill (the December 2010 draft version of the Legal Practice Bill) completely removes the option that clients currently have in terms of section $78(2 \mathrm{~A})$ of the Attorneys' Act to receive interest on their trust moneys. In terms of the Bill all trust-account interest, of whatsoever nature, must be paid over to the AFF. Should the proposed Legal Practice Bill be enacted in its present form, it would, of course, render the arguments made in this article regarding the attorney's ethical duties moot. Nevertheless, the question of the moral, legal and constitutional justification for confiscating the interest on money belonging to a client effectively for the benefit of the AFF still remains to be considered. This issue, however, is beyond the scope of this article, but will no doubt be canvassed in the future.

Robin Palmer and Angela Crocker University of KwaZulu-Natal, Durban 